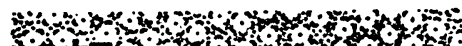 \\ (1) \\ An \\ 食品の細菌数測定法としてのスパイラル・ \\ プレーティング法の評価
}

(昭和 61 年 11 月 25 日受理)

\begin{tabular}{|c|c|c|}
\hline 和田正 道*1 & 斎藤文一*2 & 武 政 二 郎*3 \\
\hline 真 野 覚*4 & 水谷 宏 ${ }^{* b}$ & 怏英夫 ${ }^{* 6}$ \\
\hline
\end{tabular}

\section{Evaluation of the Spiral Plating Method for Bacterial Determination in Foods}

\author{
Masamichi WADA*1, Bunichi SAIT0*2, Niro TAKEMASA*3, Satoru Mano*4, \\ Hiroshi Mizutani*s, Hideo IgARASHI*8 and Hirotaka KonUMA*7
}

( ${ }^{* 1}$ Nagano Research Institute for Health and Pollution: 1978, Komemura, Amori, Nagano, Japan; *2Japan Food Research Laboratories Osaka: 3-1, Toyotsu-cho, Suita-shi, Osaka, Japan; *3Japan Oilstuff Inspectors Corporation, General Testing Research: 1-10-4, Mikagezukamachi, Higashinada-ku, Kobe, Japan; ${ }^{* 4}$ Rokko Bio-scientific Research Laboratory Co., Ltd.: 730-5, Turugasone, Yashio-shi, Saitama, Japan; ${ }^{* 5}$ Laboratory of Q.P. Corporation: 5-2, Sengawa-cho, Chofu-shi, Tokyo, Japan; ${ }^{* 6}$ Department of Microbiology, Tokyo Metropolitan Research Laboratory of Public Health: 3-24-1, Hyakunin-cho, Shinjuku-ku, Tokyo, Japan; *7Department of Microbiology, National Institute of Hygienic Sciences: 1-18-1, Kamiyoga, Setagaya-ku, Tokyo, Japan)

The spiral plating method and the pour plate method were compared in 7 laboratories for determining standard plate counts and numbers of coliforms in 5 samples each from the following 6 commercial foods; liquefied egg, pate for use with hamburger steaks, peeled shrimp, macaroni salad, minced pork, and rice ball. The 210 pooled pairs of data (as $\log _{10} \mathrm{CFU} / \mathrm{g}$ ) from the 7 laboratories were used to determine the standard plate counts and numbers of coliforms.

In determining standard plate counts, the regression line of data obtained by the pour

\footnotetext{
*1 長野県衛生公害研究所：長野県長野市大字安茂里字米村 1978

*2 日本食品分析センター大阪支所：大阪府吹田市豊津町 3-1

*3 日本油料検定協会：神戸市東灘区御影塚町 1-10-4

*4 鹿光生物科学研究所: 埼玉県八潮市鶴々曽根 730-5

*5 キューピー株式会社: 東京都調布市仙川町 2-5

*8 東京都立衛生研究所：東京都新宿区百人町 3-24-1

*7 国立衛生試験所：東京都世田谷区上用賀 1-18-1
} 
plate method versus the spiral plating method was given by $\mathrm{Y}=1.004 \mathrm{X}+0.025$, close to the theoretical line of equality. The correlation coefficient ( $r$ ) also showed the relatively high value of 0.956 . The replicate variances of both methods were not significantly different at the $5 \%$ level.

In determining numbers of coliforms, the regression line of data obtained by the pour plate method versus the spiral plating method was given by $\mathrm{Y}=0.657 \mathrm{X}+0.973$ and the correlation coefficient ( $r$ ) was 0.751 . The replicate variances of both methods were not significantly different at the $5 \%$ level.

Although standard plate counts and numbers of coliforms were determined by the same procedure, the result of the latter was less satisfactory than that of the former, because the counted numbers of red colonies on desoxycholate agar plates were dependent on each worker's subjective judgement.

This study indicates that the spiral plating method can be used in place of the pour plate method in determining the number of bacteria in commercial foods.

(Received November 25, 1986)

Key words: スパイラル・プレーティング法 spiral plating method; 一般生菌数 standard plate counts; 大腸菌群数 number of coliforms; 混釈法 pour plate method; 相関分析 correlation analysis; 回帰分析 regression analysis; F 検定 F-test

\section{緒言}

近年，医学領域の臨床検査などに抢ける自動化の影響 を受け，微生物検查の自動化も盛んに試みられている. 食品の細菌数の測定についても, 検査の迅速化, 省力化 及び検查器具, 器材などの節約を目的とした新しい测定 方法の開発が盛んに行われている(1).2). 米国のFood and Drug Administration (FDA, 食品・医薬品局) で開発 されたスパイラル・プレーティング法 ${ }^{3)}$ もの一つであ る.この方法は従来の混釈法や表面釱抹法による細菌数 測定法を考え方の基礎として, 簡易化, 迅速化, 省力化, 自動化及び検査成績の精度の向上を目的として開発され たものである.

この細菌数測定法は，米国及び英国においては，すで に評価され実用化され始めている3 ${ }^{316)}$. 我が国に扣いて も, すでに相当数の装置が輸入され, 食品関係を主とす る研究及び検查機関などで使用されるようになった，し かし，我が国に拈いては，この方法についての情報の多 くは販売会社側からの提供によるもので, このスパイラ ル・プレーティング法を使用する側による評価 ${ }^{17) ~ 21) ~ は ~}$ 十分にはなされていないのが現状である.

そこで今回，著者らは食品中の細菌数測定法としての スパイラル・プレーティング法の評洒を行らことを目的 に, 7 か所の検査機関で, 6 種類の同一食品を試料とし て，一般生菌数と大腸菌群数をスパイラル・プレーティ ング法と混釈法で測定し, 両方法で測定した值の一致性 を検討した。 また，スパイラル・プレーティング法の精 度管理的な考え方から各機関で測定した值のばらつきに ついても比較検討したので報告する.

\section{実験方法}

\section{1. 実験に参加した検查機関}

\section{長野県衛生公害研究所 \\ 日本食品分析センター大阪支所 \\ 日本油料検定協会 \\ 鹿光生物科学研究所 \\ キューピー株式会社 \\ 東京都立衛生研究所 \\ 国立衛生試験所 \\ 2. 実験の時期 \\ 1984年10月}

\section{3. 装置, 器材及び培地}

1) スパイラル・プレーター

スパイラル・プレーター (Spiral Systems, lnc. 製) は各検查機関に備えられている装置を用いた，今回の実 験には，モデル B-250 型 1 台, C 型 2 台, D 型 4 台が 使用された。

2) カウンティング・グリット付コロニービュア

コロニービュア (Spiral Systems, Inc. 製) は各検査 機関に備えられている器機を使用した.

3) ストマッカー 400

ストマッカー 400 (A. J. Seward Co. 製) は各検査機 関に備えられている器機を使用し, 食品粉砕用のポリ袋 は Konuma ら ${ }^{18)}$ の考案したフィルター付ストマッカー 袋（ストマフィルター：グンゼ産業製）を用いた。

4) チップ交換式マイクロピペット

試料の希噃を行らため, 各検査機関に備えられている 任意のチップ交換式マイクロピペットを使用した。

5) 隇菌プラスチックシャーレ

隇菌プラスチックシャーレは各検査機関で常用してい るメーカーの製品を使用した.

6) 標準寒天培地及びデオキシュレイト寒天培地 
供試した標準寒天及びデオキシコレイト寒天培地はそ れぞれ同一メーカーの同一ロット (栄研化学製) の製品 を用いた。

\section{4. スパイラル・プレーティング法に使用する平板の 調製}

標準寒天培地は $121^{\circ}, 15$ 分間, 高圧隇菌後, デオキ シコレイト寒天培地は加熱溶解後, その $20 \mathrm{ml}$ ずつを 減菌プラスチックシャーレに分注して平板とし，表面を 乾燥させてから使用した。

\section{5. 供試食品}

液卵，ハンバーガー用パティ，むきさビ，マカロニサ ラダ，豚挽肉及びおにぎりの 6 品目を用いた

液畉とハンバーガー用パティ以外の各食品は均一にな るよらに無菌的に十分混和後, 隇菌ポリ袋に均等に分割 し，シール包装して凍結した．各試料はドライアイスで 冷凍した状態で各検查機関へ送付し，実験を行うまで - $20^{\circ}$ 以下のフリーザー内に保存した.

\section{6. 細菌数の測定}

供試食品は包装したまま流水で解凍後, 直ちに無菌的 に開封して実験に供した．各食品は Konuma ら ${ }^{18)}$ の考 案したフィルター付ストマッカー袋に $10 \mathrm{~g}$ ずつ科量し, 1 種類の食品から 5 検体を調製し，6種類の食品で計30 個の検体を調製した。科量した各検体に減菌生理食塩水 $90 \mathrm{ml}$ を加え, ストマッカーで処理し，10倍希釈眯濁液 を調製した.この匙濁液について, 一般生菌数と大腸菌 群数の測定を, スパイラル・プレーティング法と混釈法 を用いて行った.

1) スパイラル・プレーティング法による細菌数の測 定

食品の 10 倍希勫懸濁液と 1,000 倍希釈懸濁液の 2 種 類を用いた， 1,000 倍希釈懸濁液は，10 倍希釈懸濁液か ら，チップ交換式マイクロピペットで $100 \mu \mathrm{l}$ を分取し, $10 \mathrm{ml}$ の隇菌生理食塩水に加えて調製した。調製した食 品の 10 倍及び 1,000 倍希釈懸濁液を, あらかじめ作製し た各 3 枚の標準寒天平板及びデオキシコレイト寒天平板 にプレーティングした. デオキシコレイト寒天平板で は, プレーティング後, あらかじめ加熱溶解し， $55^{\circ}$ に 保温した同培地を約 $5 \mathrm{ml}$ 重層した。

培養は標準寒天平板は $35^{\circ}$ ，40時間，デオキシコレイ ト寒天平板は $35^{\circ}, 24$ 時間行った.

細菌数の測定はカウンティング・グリットを備えたコ ロニービュアを用い, 集落数を肉眼で測定し, その集落 数とスパイラル・プレーティング法による試料の塗布量 から細菌数を算出する方法により行った.

2) 混釈法による細菌数の測定

各10倍希釈懸濁液を $10^{5}$ 倍まで10倍連続希釈し, 各希 釈段階の試料 $1 \mathrm{ml}$ ずつを 4 枚のシャーレに注加し， 2 枚をあらかじめ高圧隇菌し $55^{\circ}$ に保温した 標準寒天培 地で, 残りの 2 枚をあらかじめ加熱溶解し $55^{\circ}$ に保温し
たデオキシコレイト寒天培地で混釈した. 固形化後, 両 混釈平板共, 調製後 $55^{\circ}$ に保温した同種類の培地をそれ ぞれ $5 \mathrm{ml}$ ずつ重層した.

培養は標準寒天平板は $35^{\circ}$ ，48時間，デオキシコレイ ト寒天平板は $35^{\circ}, 24$ 時間行った.

細菌数の測定は常法により行った.

\section{7. 解析方法}

解析は 1 検查機関当たり 30 検体の成績を 7 か所分集計 した 210 検体の成績について行った. 一般生菌数と大腸 菌群数の成績に分けて, 各成績ごとに, 対応するスパイ ラル・プレーティング法と混釈法について, 相関係数, スパイラル・プレーティング法から混釈法の成績を推定 する回帰式，散布図にプロットした検査成績の $95 \%$ 以 上が含まれる $95 \%$ 信頼区間及び両方法の分散を算出し て比較検討した，大腸菌群数の場合，平板上に集落が検 出できなかった検体の検查成績は解析から外した，細菌 数はすべて常用対数に変換して解析を行った.

スパイラル・プレーティング法により測定された各平 板の細菌数は次に述べる 2 方法によって検体の細菌数に 計算され，混釈法との関連が別々に解析された。

第 1 の方法は検体ごとに得られた 10 倍及び 1,000 倍の 希釈段階の各 3 平板のらち, 細菌数の測定に適当な希釈 段階の 3 平板の測定値を算術平均して各検体の細菌数と した.この細菌数を用いる解析は, スパイラル・プレー ティング法を用いて, 同一検体を 3 回検査して得られた 結果の平均をとり, 混釈法との関連を求めることを意味 している，しかし，実際に日常業務としてスパイラル・ プレーティング法を用いる場合は，1 枚の平板による検 查が行われているので, このことを想定して混釈法との 関連を求めたものが第 2 の方法である.すなわち, 210 検体について, 希釈が細菌数の測定に適当な 3 平板の測 定值から，コンピューターを用いて，ランダムに 1 測定 值を選択して，その検体の細菌数とした。得られた細菌 数について第 1 の方法と同様の解析を行い, 混釈法との 関連を解析した. しかし，この方法はランダムに測定值 を選択するため, 算出される解析結果にばらつきを生じ る、このばらつきの程度を調べるため, コンピューター で同じ操作を 1,000 回繰りかえし，各解析值の平均値及 び 99\% 信頼区間值を算出し, 比較検討した.

混釈法による各検体の細菌数は, 常法どおり, 細菌数 の測定に適当な希釈段階の 2 平板の測定值を算術平均し た值とした。

\section{実 験 結果}

\section{1. スパイラル・プレーティング法と混勫法との関連}

横軸にスパイラル・プレーティング法の細菌数を, 縱 軸に混釈法の細菌 数をとった一般生菌数の散布 図を Fig. 1 亿示した. 同図には，データ数，相関係数 (r) 及 びスパイラル・プレーティング法から混釈法のデータを 推定する回帰式, 回帰直線及び95\%信頼限界を併記した. 


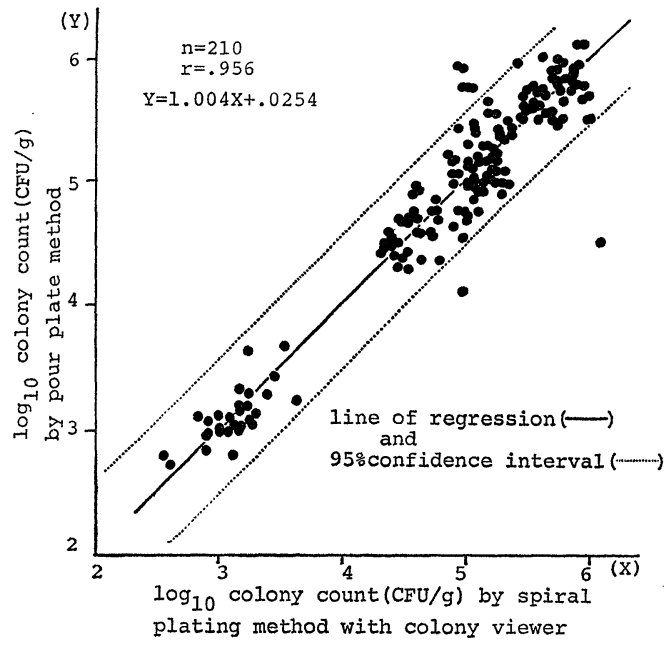

Fig. 1. Regression of data from pour plate method on the spiral plating method for determining standard plate counts

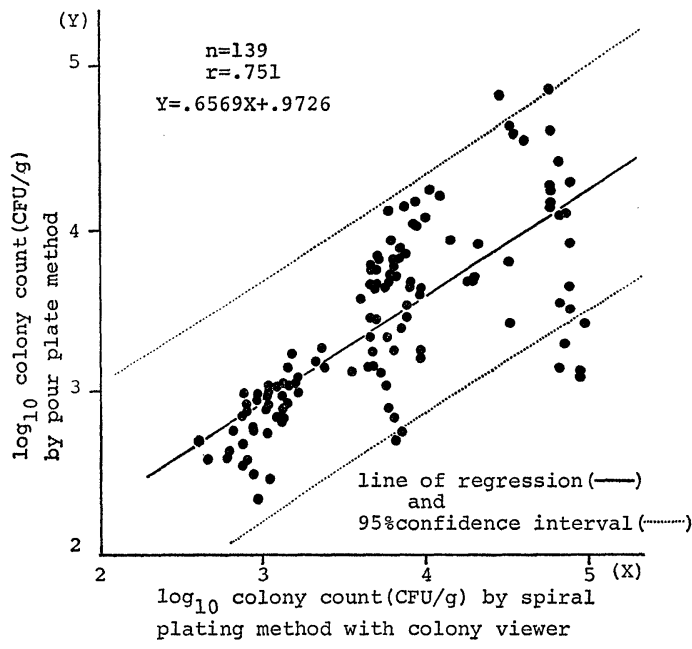

Fig. 2. Regression of data from pour plate method on the spiral plating method for determining numbers of coliforms

両方法の相関係数 (r) は 0.956, スパイラル・プレー ティング法の細菌数 (X) から混釈法 の細菌数の 推定值 (Y) を求める回帰式は $\mathrm{Y}=1.004 \mathrm{X}+0.0254$ で表せた. 95\% 信頼区間の幅は常用対数值で約 \pm 0.53 であった.

次に大腸菌群数についても，横軸にスパイラル・プレ ーティング法の細菌数を, 縱軸に混釈法の細菌数をとっ た散布図を Fig. 2 に示した. 同図には，データ数，相 関係数 (r) 及びスパイラル・プレーティング法から混釈 法のデータを推定する回帰式, 回帰直線及び $95 \%$ 信頼 限界を仿記した。
Table 1. Comparison of the Variance of Spiral Plating Method and Pour Plate Method

\begin{tabular}{lcc}
\hline & $\begin{array}{c}\text { In determining } \\
\text { standard plate } \\
\text { counts }\end{array}$ & $\begin{array}{c}\text { In determining } \\
\text { numbers of } \\
\text { coliforms }\end{array}$ \\
\hline $\begin{array}{l}\text { Variance of spiral } \\
\text { plating method }\end{array}$ & 0.7650 & 0.4095 \\
$\begin{array}{l}\text { Variance of pour } \\
\text { plate method }\end{array}$ & 0.8438 & 0.3130 \\
$\begin{array}{l}\text { F-ratio } \\
\text { (calculated value) }\end{array}$ & 1.1030 & 1.3083 \\
$\begin{array}{l}\text { F-ratio } \\
\text { (at the 5\% level) }\end{array}$ & 1.3125 & 1.3981 \\
\hline
\end{tabular}

Table 2. The Relation between Spiral Plating Method and Pour Plate Method in Determining Standard Plate Counts

\begin{tabular}{|c|c|c|}
\hline & Mean & $\begin{array}{l}99 \% \text { Confidence } \\
\text { interval }\end{array}$ \\
\hline Correlation coefficient $(r)$ & 0.9521 & $0.9520 \sim 0.9523$ \\
\hline $\begin{array}{l}\text { Regression line } \\
(\mathrm{Y}=\mathrm{aX}+\mathrm{b}): \mathrm{a}\end{array}$ & 0.9824 & $0.9814 \sim 0.9833$ \\
\hline$: \mathrm{b}$ & 0.1411 & $0.1361 \sim 0.1461$ \\
\hline $\begin{array}{l}95 \% \text { Confidence interval } \\
\text { of } \mathrm{Y} \text { value }\end{array}$ & \pm 0.5583 & $\begin{array}{l} \pm 0.5573 \sim \\
\pm 0.5592\end{array}$ \\
\hline Variance & 0.7906 & $0.7891 \sim 0.7920$ \\
\hline F-ratio (calculated) & 1.0679 & $1.0659 \sim 1.0699$ \\
\hline
\end{tabular}

One plate was selected at random from three spiral plates, and number of the colonies was counted.

The work was repeated thousand times for each sample, and the results were compared with those of pour plate method.

両方法の相関係数 (r) は 0.751 , スパイラル・プレー ティング法の細菌数 (X) から混釈法の細菌数の推定值 (Y) を求める回帰式は $\mathrm{Y}=0.6569 \mathrm{X}+0.9726$ で表せた。 95\% 信頼区間の幅は常用対数值で約 \pm 0.74 であった。

Table 1 にスパイラル・プレーティング法及び混釈法 を用いて，一般生菌数及び大腸菌群数を測定した場合の 各不偏分散の推定值と, これらから算出された両方法の 分散比である $\mathrm{F}$ 值及び $\mathrm{F}$ 分布表から得られた有意水準 $5 \%$ に打る值を示した。

一般生菌数の場合, 算出された $\mathrm{F}$ 值 1.1030 はF 分布 表から得られた $F_{209}^{209}(0.05)=1.3125$ に比べて小さく, 両方法の分散に有意差は認められなかった. また，大腸 菌群数の場合，算出された $\mathrm{F}$ 值 1.3083 は F 分布表から 得られた $F_{138}^{138}(0.05)=1.3981$ に比べて小さく, 両方法 の分散に有意差は認められなかった. なお, 検定方法は 両側検定とした.

2. ランダムに 1 測定值を選択した場合のスパイラ ル・プレーディング法と混釈法との関連 
Table 3. The Relation between Spiral Plating Method and Pour Plate Method in Determining Numbers of Coliforms

\begin{tabular}{|c|c|c|}
\hline & Mean & $\begin{array}{l}99 \% \text { Confidence } \\
\text { interval }\end{array}$ \\
\hline Correlation coefficient ( $\mathrm{r}$ ) & 0.7457 & $0.7449 \sim 0.7465$ \\
\hline $\begin{array}{l}\text { Regression line } \\
(\mathrm{Y}=\mathrm{aX}+\mathrm{b}): \mathrm{a}\end{array}$ & 0.6274 & $0.6262 \sim 0.6285$ \\
\hline$: \mathrm{b}$ & 1.0959 & $1.0913 \sim 1.1004$ \\
\hline $\begin{array}{l}95 \% \text { Confidence interval } \\
\text { of } Y \text { value }\end{array}$ & \pm 0.7415 & $\begin{array}{l} \pm 0.7404 \sim \\
\pm 0.7426\end{array}$ \\
\hline Variance & 0.4433 & $0.4419 \sim 0.4446$ \\
\hline F-ratio (calculated) & $1.4162^{*}$ & $\begin{array}{l}* 1.4117^{*} \\
\quad \sim 1.4207^{*}\end{array}$ \\
\hline
\end{tabular}

*: Significance at the $5 \%$ level

One plate was selected at random from three spiral plates, and number of the colonies was counted.

The work was repeated thousand times for each sample, and the results were compared with those of pour plate method.

一般生菌数について， 3 平板の各測定値から, ランダ ムに 1 測定值を選択した場合のスパイラル・プレーティ ング法と混釈法との関連を, コンピューターで 1,000 回 繰り返して算出した, 各解析值の平均值と $99 \%$ 信頼限 界を Table 2 に示した.

Fig. 1 に示した 3 平板の測定值の算術平均值を用い て解析した場合に比べて，相関係数，回帰式及び $95 \%$ 信頼限界には大きな变動は認められなかった。 また, 分 散についても大きな変動は認められず，同様に F 值の検 定を行った結果, 両方法の分散には有意差が認められな かった。

大腸菌群数について，3 平板の各測定值から，ランダ ムに 1 測定值を選択した場合のスパイラル・プレーティ ング法と混釈法との関連を, コンピューターで 1,000 回 繰り返して算出した, 各解析值の平均值と $99 \%$ 信頼限 界を Table 3 に示した.

Fig. 2 に示した 3 平板の測定値の算術平均值を用い て解析した場合に比べて，相関係数，回帰式及び $95 \%$ 信頼限界には大きな变動は認められなかった. しかし， 分散については約 $10 \%$ の変動が認められ， F 值の検定 を行った結果, 両方法の分散には有意差が認められた.

\section{考察}

一般生菌数の測定については，スパイラル・プレーテ ィング法を 1 検体につき 3 枚の平板を用いて行い, 平均 をとった場合に得られる混釈法との相関は, 統計的な一 般的基準からみて，相当高いと考えられる. さらに，回 埽式は $\mathrm{Y}=\mathrm{X}$ に近接していると考学られる. 以上の二 点から，スパイラル・プレーティング法と混釈法によっ
て得られる測定值は統計的にみて同一とみなせると考え る. また， 3 平板の測定值から 1 测定值をランダムに選 択した解析から，スパイラル・プレーティング法を平板 1 枚で行って子，混釈法と同一とみなせる測定值が得ら れると考えられる. 両方法の精度の比較については, 分 散の検討に拈いて，スパイラル・プレーティング法の平 均をとった場合と 1 測定值をランダムに選択した場合は 共に，混釈法との間に有意美を認めないことから，スパ イラル・プレーティング法と混釈法には差がないと認め られる.

大腸菌群数の測定については，スパイラル・プレーテ ィング法の 3 平板の測定值の平均をとった場合と 3 平板 の測定値からランダムに 1 測定值を 選択した場合は共 に，混釈法の測定值との間に差が認められた。 また，精 度に関しても，3 平板の測定値からランダムに 1 測定値 を選択した場合には，混釈法の湘定値との間に差が認め られた．両方法の測定値に差が生じた理由は，大腸菌群 数の測定の場合, デオキシコレイト寒天平板に発育した 赤色集落のみを選択して数えるが，そのとき，集落の大 きさ及び色調の違いに対する検查者の主観によって, 大 腸菌群として数えたり, 数えなかったりすることに起因 すると考えられる．この現象は，スパイラル・プレーテ ィング法と混釈法で，同等に起り得ると考光られる. 従 って，それを補正するためには，あらかじめ集落の大き さ及び色調などの判定基準を決めて，検査者をトレーニ ングして括けば，より良い成績が得られると思われる が, 根本的には, 検查者の主観が入らないようにするた め, 発育した集落をすべて大腸菌群として数えられるよ らな培地の積極的な開発が必要であると考えている.

以上の成績から，スパイラル・プレーティング法は， 本質的に, 混釈法の測定值と高い一致性が認められ, 精 度についても, 混釈法との間で有意差が認められないと 考学られる。

また，今回の実験は 7 か所の検査機関で，それぞれ異 なった検査環境のもとで，異なった機種のスパイラル・ プレーターを用いて検査した成績を比較検討したが，機 種の違いによる影響は認められず，混釈法と同一とみな せる測定值が得られたことは, 細菌数測定に打ける, ス パイラル・プレーティング法の再現性の高さを示すもの である。

著者らの成績以外飞も，菌液3).12) 14),17),20), 乳 及び乳製品 $\left.\left.\left.\left.\left.{ }^{3}, 4\right), 7\right), 8\right), 14\right), \sim 16\right)$, 化粧品 ${ }^{6)}$ 及び一般の食 品6),7).11).13),14),16) 19)などについて，スパイラル・プレ 一ティング法と混釈法などによる細菌数の一致性を証明 した成績が, 数多くの研究者によって, 報告されてい る。また，精度についても，混釈法などとの間に差が認 められない成績 $\left.\left.\left.{ }^{3)}, 4\right), 7\right), 83,14\right)$ 20) が多数報告されている.

従って，スパイラル・プレーティング法が広く普及し ても, 混釈法に比べて, 検査成績の差異や, 精度の低下 
が起るとは考えられず, 将来, 全国的規模で, 食品の 細菌数検査が実施されるよらなことが生じたとき，混 釈法に比ベて, 迅速性, 省力性及び省資材性に優れ る4),7),14),18),20) スパイラル・プレーティング法は非常に 有効になってくるよらに思われる.

著者らの 7 検査機関の検査成績はその可能性を示唆し ているものと考えている.

\section{要 約}

7 か所の検査機関において，6 種類の食品の一般生菌 数と大腸菌群数の测定を, スパイラル・プレーティング 法と混釈法を用いて行い，その成績を統計的に比較検討 した.

一般生菌数については，両方法の測定值及び精度には 有意差は認められない。

大腸菌群数については, 両方法の測定值及び精度には 有意差が認められた。この原因は，デオキシコレイト寒 天培地を用いる集落数の測定に, 検査者の主観が入るこ とに起因すると考えられる. この現象は両方法で同等に 起ると考えられる.

これらの成績から，スパイラル・プレーティング法 は, 本質的に, 混釈法の測定值と高い一致性が認められ， 精度については，混釈法との間に有意差が認められない と考えられる。

実験は，7 か所の検査機関で，それぞれ異なった機器 を用いて行われたが，混釈法と同一とみなせる測定值が 得られた. このことは，スパイラル・プレーティング法 の再現性の高さを示すと考えられる.

以上の成績及び考察に，これまでに報告された迅速 性, 省力性及び省資材性に優れる点を加えると, 将来, スパイラル・プレーティング法は非常に有効になってく ると思われる。

本報告の要旨は日本食品衛生学会第49回学 術講 演 会 (1985年 5 月，東京）に拈いて発表した。また，本研究は 「昭和59年度厚生科学研究費補助金」の交付を受けて行 った.

\section{謝辞}

本研究を行うに当り，ハンバーグ用のパティを頂いた 埼玉県衛生研究所 德丸雅一先生, 並びに, 御協力頂い たグンゼ産業 (株) 理化学機器部の皆様に深謝します.

\section{文献}

1）森地敏樹：食品衛生研究 34, 23 38 (1984).

2) 春田三佐夫，坂崎利一，森地敏樹編：“食品微生 物検查の簡易化，自動化，迅速化”(1984) サイエ ンスフォーラム。

3) Gilchrist, J. E., Campbell, J. E., Donnelly, C.
B., Peeler, J.T., Delaney, J.M.: Appl. Microbiol. 25, 244 252 (1973).

4) Donnelly, C. B., Gilchrist, J. E., Peeler, J. T., Campbell, J. E.: Appl. Environ. Microbiol. 32, $21 \sim 27$ (1976).

5) Assoc. Off. Anal. Chem.: J. Assoc. Off. Anal. Chem. 60, 493 494 (1977).

6) Gilchrist, J. E., Donnelly, C. B., Peeler, J. T., Campbell, J.E.: ibid. 60, 807 812 (1977).

7) Jarvis, B., Lach, V.H., Wood, J.M.: J. Appl. Bacteriol. 43, 149 157 (1977).

8) Peeler, J. T., Gilchrist, J. E., Donnelly, C. B., Campbell, J.E.: J. Food Protect. 40, 462 464 (1977).

9) American Public Health Association: "Standard Methods for the Examination of Dairy Products 14th ed." p. 317 324 (1978).

10) Food and Drug Administration, Division of Microbiology: "Bacteriological Analytical Manual for Foods 5th ed." p. IV-5 IV-9 (1978).

11) Baumgart, J.: Fleischwirtschaft 58, 465 466 (1978).

12) Hedges, A. J., Shannon, R., Hobbs, R. P.: J. Appl. Bacteriol. 45, 57 65 (1978).

13) Gerats, G. E., Snijders, J.M.A.: Fleischwirtschaft 59, 256 258 (1979).

14) Kramer, J. M., Kendall, M., Gilbert, R. J.: European J. Appl. Microbiol. Biotechnol. 6, $289 \sim 299$ (1979).

15) Griffiths, M. W., Phillips, J. D., Muir, D. D.: J. Soci. Dairy Technol. 33, 8〜10 (1980).

16) Zipkes, M. R., Gilchrist, J. E., Peeler, J. T.: J. Assoc. Off. Anal. Chem. 64, 1465 1469 (1981).

17）五十嵐英夫：メディアサークル 27，98１11 (1982).

18) Konuma, H., Suzuki, A., Kurata, H.: Appl. Environ. Microbiol. 44, 765 769 (1982).

19）和田正道, 村松紘一, 小林正人, 笹井貞雄: 食品 と微生物 1, 137 142 (1984).

20）小沼博隆，尾上洋一，倉田 浩：衛生試報。102, 49 54 (1984)

21）春田三佐夫，坂崎利一，森地敏樹編：“食品微生 物検查の簡易化，自動化，迅速化” p. $27 \sim 36$ (1984) サイエンスフォーラム。 